\title{
Labour costs and \\ competitiveness in the Latin American manufacturing sector, 1990-1998
}

\section{Víctor E. Tokman}

Regional Director,

International Labour

Organisation (ILO).

\section{Daniel Martínez}

Staff member of the

ILO Regional Office

for the Americas. 


\section{Introduction}

Some of the most important changes in labour and social security legislation in recent years have been aimed at reducing labour costs. The argument has been that as labour costs are a major component in total production costs, their reduction would make it possible to lower the cost of the goods produced or the services provided, thus making the enterprises favoured by this policy more competitive.

The policy of reducing labour costs is reflected in two strategies which are sometimes applied simultaneously: on the one hand, reducing social security contributions and labour taxes -that is to say, the non-wage component of total labour costs- and on the other, encouraging the hiring of certain types of workers (especially young people without previous work experience and workers who have been out of a job for a long time) through subsidies and/or tax exemptions.

The aim of the latter strategy is to reduce the cost of hiring such workers and thus encourage their employment. In the case of young people, for example, it is necessary to weigh the relative cost of employing an inexperienced young person of lower productivity against that of employing an experienced adult worker. These relative costs are balanced if the State absorbs part of the non-wage labour cost of the worker in question (mainly the social security costs), thus reducing the labour burdens or taxes for the employer, or if the employer is exempted from all or part of the contributions he would otherwise be obliged to pay under the labour legislation.

This new approach to labour and social security legislation (which, of course, also has other aims as well as the reduction of costs) has given rise to considerable discussion. In general, employers consider that reducing labour costs, together with more flexible forms of hiring and greater mobility of workers within the firm, will make companies more competitive because they will be able to offer their products

$\square$ The views expressed in this study do not necessarily represent the official position of the ILO. at more interesting prices and will be able to adapt their organization and labour force more easily to changes in demand.

For their part, although workers acknowledge the importance of reducing business costs they fear adverse repercussions on their income and/or on the extent and quality of protection systems, especially as regards health and pensions.

The question arises, then, as to whether it is really necessary to reduce labour costs in order to make firms more competitive. This study seeks to provide an answer to that question. For reasons of availability of information, we have limited our analysis to the manufacturing sector, and productivity refers to labour and not to the totality of the factors involved. ${ }^{1}$

This article is an updated and expanded version of an earlier study (ILO, 1997) and seeks to estimate changes in the level of competitiveness on the basis of variations in productivity and average labour costs. This latter aspect (average labour costs) was not taken into account in the original study, as on that occasion the labour cost analysed was that of a worker with a "permanent" contract. However, as in recent years there has been a significant increase in the demand for workers on fixed-term contracts and, even more so, for unregistered workers without any social security coverage, it was considered that the cost of an employee with a permanent contract did not properly reflect the average labour costs in the industrial sector. We have therefore estimated the average cost given by the sum of the costs of workers on each type of contract (and also of workers without any contract), weighted by the share of each of these types of worker in the overall industrial employment structure. Likewise, the data on labour productivity used here refer to the value added per hour worked and not, as in the original publication, the physical output per hour worked.

\footnotetext{
${ }^{1}$ Although productivity, defined in this way, refers to only a single factor, it generally displays a correlation with total factor productivity. Hofman (1996) shows that this was so in the cases of Argentina, Chile and Mexico in the period from 1950 to 1992.
} 


\section{II}

\section{Evolution of non-wage labour costs in the manufacturing sector}

Non-wage labour costs are generally calculated as the percentage of the gross wage that the employer must pay in addition to cover the social security benefits laid down in each country's legislation. Most studies also include deferred wages in respect of bonuses ("Thirteenth month", etc.) and holidays. However, both the contributions that must be paid by the employer and the deferred wages in respect of bonuses and holidays are calculated on the basis of the legislation applicable to workers with permanent contracts, and do not take account of the fact that in some countries workers with fixed-term contracts are subject to different treatment, while in the case of workers without a contract employers do not make any -or hardly any- social security contributions at all. In this section we therefore make a distinction between the non-wage labour costs of each of these three types of workers.

\section{Non-wage labour costs of workers with permanent contracts}

In the countries studied, the evolution of the workers' social security deductions ${ }^{2}$ has been as follows: in Argentina they rose from $14 \%$ of gross wages in 1980 to $16 \%$ in 1990 and $17 \%$ in 1998 (table 1). In Peru, they rose from 6\% in 1990 to $19 \%$ in 1994 , because of the pension system reform, but were later reduced to $11.4 \%$. In the other countries they remained constant: $21 \%$ in Chile and between $9 \%$ and $5 \%$ in Brazil, Colombia and Mexico. It should be noted that in Chile, as in Peru, the deductions had been raised earlier because of the privatization of the pension system.

The bigger deductions paid by workers in Chile and Peru are due to pension system reform, which shifted the entire responsibility for financing the

\footnotetext{
2 The term "deductions" is used to refer to the amount deducted from a worker's gross wage to cover his labour benefits, while "contributions" refers to the amount, over and above a worker's wages, that his employer must pay for the same purpose.
}

system to the workers, so that they now have to pay the contributions previously made by their employers, as well as the share they had always paid themselves under the old system. These increased deductions were offset by a proportional increase in gross wages.

On the employers' side, their overall contributions (as a percentage of gross wages) evolved as follows: in Argentina they were reduced from 59.6\% in 1980 to $56.1 \%$ in 1990 and $44.8 \%$ in 1998 (table 1); in Brazil they rose slightly from $57.6 \%$ in 1990 to $58.2 \%$ of the gross wage in 1994 and have since remained unchanged at that level; in Chile they have stood at $38 \%$ since the labour reforms of the 1980s; in Colombia they went down from $47.6 \%$ in 1980 to $46.8 \%$ in 1990 but rose again to $49 \%$ in 1998 , and in Peru they likewise went down from $66.8 \%$ in 1990 to $62.9 \%$ in 1994 only to rise again later to $65.6 \%$.

In relative terms (total contributions and other costs payable by employers/costs payable by workers), contributions range from close to $40 \%$ in Peru to $27.5 \%$ in Chile. In Argentina they amount to $31 \%$ and in Brazil, Colombia and Mexico to around 35\%.

The calculations of non-wage labour costs made in this article differ from the estimates made in other studies and even in previous studies by the ILO itself. There are two reasons for this. Firstly, the rates used in such areas as accident insurance, family allowances and severance pay are estimated averages, adjusted yearly on the basis of the information provided by firms and official bodies for the year before the date of the study. Consequently, as the studies are updated the rates are modified to reflect more accurately what actually occurred. Secondly, in some countries the calculation methodology used has been changed. This is so, for example, in the case of supplementary income in Chile: this is estimated to be equivalent to $19.8 \%$ of gross wages, bearing in mind that most Chilean wage-earners have a monthly income equal to twice the official minimum wage, in contrast with earlier studies in which average income was taken as being equal to the minimum wage and a 
TABLE 1

Argentina, Brazil, Chile, Colombia, Mexico and Peru: Breakdown of non-wage labour costs of permanent and temporary workers

\begin{tabular}{|c|c|c|c|c|c|}
\hline \multicolumn{6}{|c|}{ Argentina } \\
\hline & \multirow{2}{*}{$\begin{array}{c}1980 \\
\text { Permanent }\end{array}$} & \multirow{2}{*}{$\begin{array}{c}1990 \\
\text { Permanent }\end{array}$} & \multirow{2}{*}{$\begin{array}{c}1994^{\mathrm{a}} \\
\text { Permanent }\end{array}$} & \multicolumn{2}{|c|}{1998} \\
\hline & & & & Permanent & Temporary \\
\hline A. Gross remuneration & 100.0 & 100.0 & 100.0 & 100.0 & 100.0 \\
\hline Net monthly remuneration ${ }^{b}$ & 97.1 & 95.1 & 94.1 & 91.3 & \\
\hline B. Worker's contributions & 14.0 & 16.0 & 17.0 & 17.0 & \\
\hline Pension & 11.0 & 10.0 & 11.0 & 11.0 & \\
\hline Social welfare ${ }^{c}$ & 4.0 & 6.0 & 6.0 & 6.0 & \\
\hline C. Employer's contributions & 59.6 & 56.1 & 56.1 & 44.8 & 30.9 \\
\hline 1. Contributions & 43.9 & 40.4 & 40.4 & 29.1 & 17.7 \\
\hline Pension & 15.0 & 11.0 & 16.0 & 9.9 & 5.0 \\
\hline Social welfare ${ }^{c}$ & 4.5 & 8.0 & 8.0 & 6.2 & 5.1 \\
\hline Family allowances & 12.0 & 9.0 & 7.5 & 4.7 & 2.3 \\
\hline Unemployment fund & - & - & 1.5 & 0.9 & 0.5 \\
\hline $\operatorname{IPD}^{\mathrm{d}^{\mathrm{t}}}$ & 5.4 & 5.4 & 5.4 & 5.4 & 2.8 \\
\hline Accident insurance & 2.0 & 2.0 & 2.0 & 2.0 & 2.0 \\
\hline Housing fund & 5.0 & 5.0 & - & - & - \\
\hline 2. Other costs payable by employer & 15.7 & 15.7 & 15.7 & 15.7 & 13.2 \\
\hline Supplementary payments ${ }^{\mathrm{e}}$ & 8.3 & 8.3 & 8.3 & 8.3 & 8.3 \\
\hline Holidays & 7.4 & 7.4 & 7.4 & 7.4 & 4.9 \\
\hline D. Total cost $(A+C)$ & 159.6 & 156.1 & 156.1 & 144.8 & 130.9 \\
\hline $\mathrm{Ce} / \mathrm{Ct}^{\mathrm{f}}$ & 37.3 & 35.9 & 35.9 & 30.9 & 23.6 \\
\hline \multicolumn{6}{|c|}{ Brazil } \\
\hline & & 1990 & 1994 & \multicolumn{2}{|c|}{1998} \\
\hline & & Permanent & Permanent & Permanent & Temporary \\
\hline A. Gross remuneration & & 100.0 & 100.0 & 100.0 & 100.0 \\
\hline Net monthly remuneration & & 99.3 & 99.3 & 99.3 & \\
\hline B. Worker's contributions & & 9.0 & 9.0 & 9.0 & \\
\hline Pension & & 9.0 & 9.0 & 9.0 & \\
\hline C. Employer's contributions & & 57.6 & 58.2 & 58.2 & 37.2 \\
\hline 1. Contributions & & 38.2 & 38.8 & 38.8 & 25.9 \\
\hline Social security & & 20.0 & 20.0 & 20.0 & 20.0 \\
\hline Ind. Social Services & & 1.5 & 1.5 & 1.5 & 0.75 \\
\hline Ind. Training Services & & 1.0 & 1.0 & 1.0 & 0.5 \\
\hline \multicolumn{6}{|c|}{ National Institute for Land Settlement and Agrarian } \\
\hline Reform & & 0.2 & 0.2 & 0.2 & 0.1 \\
\hline Education & & 2.5 & 2.5 & 2.5 & 1.25 \\
\hline \multicolumn{6}{|c|}{ Brazilian Small and Medium-sized Enterprise } \\
\hline Support Service & & - & 0.6 & 0.6 & 0.3 \\
\hline Length of Service Guarantee Fund & & 8.0 & 8.0 & 8.0 & 2.0 \\
\hline Accident insurance & & 2.0 & 2.0 & 2.0 & 1.0 \\
\hline Severance compensation & & 3.0 & 3.0 & 3.0 & - \\
\hline 2. Other costs payable by employer & & 19.4 & 19.4 & 19.4 & 11.3 \\
\hline Supplementary payments & & 8.3 & 8.3 & 8.3 & 8.5 \\
\hline Holidays & & 11.3 & 11.3 & 11.1 & 2.8 \\
\hline D. Total cost $(A+C)$ & & 157.6 & 158.2 & 158.2 & 137.2 \\
\hline $\mathrm{Ce} / \mathrm{Ct}^{\mathrm{f}}$ & & 36.5 & 36.8 & 36.8 & 27.1 \\
\hline
\end{tabular}


TABLE 1 (Continued)

Chile

\begin{tabular}{|c|c|c|c|c|}
\hline & & $\begin{array}{c}1990 \\
\text { Permanent }\end{array}$ & $\begin{array}{c}1994 \\
\text { Permanent } \\
\end{array}$ & $\begin{array}{c}1998 \\
\text { Permanent }\end{array}$ \\
\hline A. Gross remuneration & & 100.0 & 100.0 & 100.0 \\
\hline Net remuneration ${ }^{\mathrm{b}}$ & & 98.7 & 98.7 & 98.7 \\
\hline B. Worker's contributions & & 21.1 & 21.1 & 21.1 \\
\hline Pension & & 13.5 & 13.5 & 13.5 \\
\hline Health insurance & & 7.0 & 7.0 & 7.0 \\
\hline Accident insurance & & 0.6 & 0.6 & 0.6 \\
\hline C. Employer's contributions & & 38.0 & 38.0 & 38.0 \\
\hline 1. Contributions & & 10.9 & 10.9 & 10.9 \\
\hline Severance compensation fund & & 8.3 & 8.3 & 8.3 \\
\hline Accident insurance $\mathrm{g}^{\mathrm{g}}$ & & 2.6 & 2.6 & 2.6 \\
\hline 2. Other costs payable by employer & & 27.1 & 27.1 & 27.1 \\
\hline Holidays & & 7.3 & 7.3 & 7.3 \\
\hline Supplementary payments $\mathrm{h}$ & & 19.8 & 19.8 & 19.8 \\
\hline D. Total cost $(A+C)$ & & 138.0 & 138.0 & 138.0 \\
\hline $\mathrm{Ce} / \mathrm{Ct}^{\mathrm{f}}$ & & 27.5 & 27.5 & 27.5 \\
\hline \multicolumn{5}{|c|}{ Colombia } \\
\hline & \multicolumn{2}{|c|}{1988} & \multicolumn{2}{|c|}{1996} \\
\hline & Permanent & Temporary & Permanent & Temporary \\
\hline A. Gross remuneration & 100.0 & 100.0 & 100.0 & 100.0 \\
\hline Net remuneration ${ }^{\mathrm{b}}$ & & & 100.9 & 100.9 \\
\hline B. Worker's contributions & & & 7.4 & 7.4 \\
\hline Pension & & & 3.4 & 3.4 \\
\hline Health insurance ${ }^{\mathrm{k}}$ & & & 4.0 & 4.0 \\
\hline \multicolumn{5}{|l|}{ Accident insurance } \\
\hline C. Employer's contributions & 47.6 & 29.3 & 52.9 & 52.9 \\
\hline 1. Contributions & 33.5 & 29.3 & 38.8 & 38.8 \\
\hline Health insurance ${ }^{\mathrm{k}}$ & 4.7 & 4.7 & 8.0 & 8.0 \\
\hline Pension & 4.3 & 4.3 & 10.1 & 10.1 \\
\hline Severance compensation fund & $13.5^{\mathrm{i}}$ & 9.3 & 9.3 & 9.3 \\
\hline National Training Service & 2.0 & 2.0 & 2.0 & 2.0 \\
\hline Accident insurance & 2.0 & 2.0 & 2.4 & 2.4 \\
\hline Family allowances & 4.0 & 4.0 & 4.0 & 4.0 \\
\hline Family Welfare Institute & 3.0 & 3.0 & 3.0 & 3.0 \\
\hline 2. Other costs payable by employer & 14.1 & - & 14.1 & 14.1 \\
\hline Holidays & 5.8 & - & 5.8 & 5.8 \\
\hline Supplementary payments ${ }^{\mathrm{j}}$ & 8.3 & - & 8.3 & 8.3 \\
\hline D. Total cost $(A+C)$ & 147.6 & 129.3 & 152.9 & 152.9 \\
\hline $\mathrm{Ce} / \mathrm{Ct} \mathrm{f}^{\mathrm{f}}$ & 32.2 & 22.7 & 34.6 & 34.6 \\
\hline \multicolumn{5}{|c|}{ Mexico } \\
\hline & 1980 & 1990 & 1994 & 1998 \\
\hline & Permanent & Permanent & Permanent & Permanent \\
\hline A. Gross remuneration & 100.0 & 100.0 & 100.0 & 100.0 \\
\hline Net remuneration ${ }^{b}$ & 105.9 & 105.9 & 105.9 & 105.9 \\
\hline B. Worker's contributions & 5.1 & 5.1 & 5.1 & 5.1 \\
\hline Pension & 2.1 & 2.1 & 2.1 & 2.1 \\
\hline Health insurance $^{\mathrm{k}}$ & 3.0 & 3.0 & 3.0 & 3.0 \\
\hline C. Employer's contributions & 40.6 & 46.8 & 48.7 & 48.8 \\
\hline 1. Contributions & 19.0 & 25.2 & 27.1 & 27.2 \\
\hline Pension & 3.8 & 4.2 & 5.7 & 5.8 \\
\hline Health insurance ${ }^{\mathrm{k}}$ & 5.6 & 8.4 & 8.8 & 8.8 \\
\hline Day Nurseries & 1.0 & 1.0 & 1.0 & 1.0 \\
\hline Retirement & - & 2.0 & 2.0 & 2.0 \\
\hline Accident insurance & 2.6 & 2.6 & 2.6 & 2.6 \\
\hline Housing fund & 5.0 & 5.0 & 5.0 & 5.0 \\
\hline Wage tax & 1.0 & - & - & - \\
\hline Payroll tax & - & 2.0 & 2.0 & 2.0 \\
\hline 2. Other costs payable by employer & 21.6 & 21.6 & 21.6 & 21.6 \\
\hline Supplementary payments & 11.0 & 11.0 & 11.0 & 11.0 \\
\hline Holidays & 10.6 & 10.6 & 10.6 & 10.6 \\
\hline D. Total cost $(A+C)$ & 140.6 & 146.8 & 148.7 & 148.8 \\
\hline $\mathrm{Ce} / \mathrm{Ct}^{\mathrm{f}}$ & 28.9 & 31.9 & 32.8 & 32.8 \\
\hline
\end{tabular}


TABLE 1 (Concluded)

Peru

\begin{tabular}{|c|c|c|c|}
\hline & $\begin{array}{c}1990 \\
\text { Permanent }\end{array}$ & $\begin{array}{c}1994 \\
\text { Permanent }\end{array}$ & $\begin{array}{c}1998 \\
\text { Permanent }\end{array}$ \\
\hline A. Gross remuneration & 100.0 & 100.0 & 100.0 \\
\hline Net remuneration ${ }^{b}$ & 113.0 & 100.0 & 108.4 \\
\hline B. Worker's contributions & 6.0 & 19.0 & 11.4 \\
\hline Pension $^{1}$ & 3.0 & 16.0 & 11.4 \\
\hline Health insurance & 3.0 & 3.0 & - \\
\hline C. Employer's contributions & 66.8 & 62.9 & 65.6 \\
\hline 1. Contributions & 36.8 & 32.9 & 35.85 \\
\hline Pension & 6.0 & - & - \\
\hline Health insurance & 6.0 & 6.0 & 9.0 \\
\hline Accident insurance ${ }^{\mathrm{m}}$ & 3.0 & 4.0 & 4.0 \\
\hline Housing fund & 6.0 & 6.0 & 5.0 \\
\hline SENATI (training) & 1.5 & 1.2 & 0.75 \\
\hline CTS (severance compensation) & 8.3 & 9.7 & 9.7 \\
\hline Family allowances & 6.0 & 6.0 & 7.4 \\
\hline 2. Other costs payable by employer & 30.0 & 30.0 & 29.7 \\
\hline Holidays & 11.0 & 11.0 & 9.9 \\
\hline Supplementary payments & 19.0 & 19.0 & 19.8 \\
\hline D. Total cost $(A+C)$ & 166.8 & 162.9 & 165.6 \\
\hline $\mathrm{Ce} / \mathrm{Ct}^{\mathrm{f}}$ & 40.0 & 38.6 & 39.6 \\
\hline
\end{tabular}

Source: Prepared by the ILO on the basis of official information.

a The employers' contributions for pensions, social welfare, family allowances and the unemployment fund were reduced in 1994 by $30 \%$

in Buenos Aires and by $80 \%$ in the poorest provinces. It is estimated that the average reduction was $40 \%$.

b Net remuneration $=$ gross remuneration - worker's contributions + supplementary income.

c Health insurance, including contribution to the National Institute of Social Services for Retired Persons (INSSJ\&P).

d Severance compensation. The 1994 rate was assumed for 1980 and 1990.

e Corresponds to bonuses or extra wages.

f $\mathrm{Ce}=$ contributions and other costs payable by the employer; $\mathrm{Ct}=$ costs payable by workers.

g Average rate; maximum rate $=3.9 \%$.

h Workers' participation in profits, with average wage equal to 2 official minimum wages.

i Includes retroactive unemployment benefits.

j Corresponds to bonuses or extra wages.

k Mexican Social Security Institute: private sector.

1 Industrial worker enrolled in a private Pension Fund Management Company (AFP).

$\mathrm{m}$ Average. Rates range from $1.0 \%$ to $12.2 \%$.

rate of $25 \%$ was applied. Furthermore, these calculations do not include the cost of such items as official holidays and Sundays, maternity leave, sick leave, etc., for the reasons explained in ILO (1997).

\section{Non-wage labour costs of workers with temporary contracts, or with no contract at all}

In three of the countries studied (Chile, Mexico and Peru), ${ }^{3}$ the rates of contributions applied to workers with temporary contracts under the current legislation are the same as for workers with permanent contracts, but in the other three (Argentina, Brazil and

\footnotetext{
${ }^{3}$ Obviously, the costs in respect of deferred wages, length of service, severance pay, etc., are proportional to the duration of the contract.
}

Colombia) they are different. In Argentina, the non-wage labour costs for these workers averaged $30.9 \%$ of gross wages (14 percentage points less than for a worker with a permanent contract and nearly 15 points less than in 1990, when there was no promotion of temporary contracts). In Brazil, it is estimated that the non-wage labour costs for a worker with a fixed-term contract amount to $37.2 \%$ of his gross wage: 21 percentage points less than those for a permanent worker. In Colombia, the non-wage labour costs for a temporary worker have increased from $29.2 \%$ of the gross wage in 1988 (before Law 50) to $52.9 \%$ at present, bringing them up to a similar level to that of a worker with a permanent contract.

We thus see that, except in Colombia, the non-wage costs for temporary workers have remained unchanged or gone down, which (together 
with the fact that they receive lower wages than permanent workers) should give rise to greater demand for this type of worker. Although this has in fact occurred, it is interesting to note that there has not been an even bigger increase in the demand for unregistered workers, who receive lower wages than temporary workers and whose employers do not pay social security contributions for them. ${ }^{4}$ As noted by Szretter (1999), the use of unregistered workers may form part of a broader strategy of tax evasion by some firms.

To sum up, then, in all the countries studied, except Chile and Brazil, there have been changes in the level of overall labour contributions, calculated as a percentage of gross wages. In Argentina thay have gone down, while in Colombia, Mexico and Peru they have increased slightly. In Chile, Colombia and Peru there is no difference between the non-wage labour costs of permanent and temporary workers, but in Argentina and Brazil the employers' contribution in respect of temporary workers is lower. In Argentina this difference is due to the established legislation, whereas in Brazil it is a matter of custom. Colombia is in a special situation, as although the rates of contributions are now similar for both types of contracts, this was not so in 1988. Law No. 50 adopted in 1990 made it relatively more expensive to hire temporary labour.

\section{III}

\section{Trade openness and relative prices: their effects on labour costs and competitiveness}

In the following analysis, we adopt the hypothesis that there will be gains in competitiveness when labour productivity rises faster than labour costs. When the labour costs are calculated in national currency, however, in order to estimate their real level it is necessary to decide what index to use: the consumer price index (CPI) or the producer price index (PPI). This decision is not devoid of importance, since in the first few years after the initiation of trade openness the two indexes evolve at different rates. The CPI grows faster than the PPI and hence the growth of real labour costs is smaller when deflated by the CPI than it is when deflated by the PPI. As workers are keen to defend the purchasing power of their wages (that is to say, in relation to the CPI), they tend to feel that the CPI does not rise sufficiently. In contrast, when making their economic calculations entrepreneurs take into account the rise in the firm's costs (including labour costs) compared with the evolution of their products' prices (the PPI), and

${ }^{4}$ In some firms, however, the employer may pay their holidays and bonuses or other types of extra pay. therefore perceive that when defined in this way the growth of the index affects their competitiveness. In this situation, which occurs in the early years of the openness process, both sides -workers and employers- have opposite but equally justifiable attitudes to the evolution of real labour costs.

The change in relative prices, depending on whether they are based on the CPI and the PPI, is due to the fact that the evolution of consumer prices more strongly reflects the growth rate of the prices of non-tradeable goods and services, which are usually slower to adjust because they are less exposed to the greater outside competition generated by trade openness, whereas the evolution of producer prices is more affected by the prices of tradeable goods, which are quickly affected by trade openness and tend to come into line with international prices.

Later on, once firms have adjusted to market conditions, made improvements in their organization of production and labour, and invested in technology and staff training, the effect of competition shifts to the non-tradeable goods sector. Relative prices then begin to stabilize and the different perceptions of employers and workers on the evolution of labour costs tend to disappear. 
TABLE 2

Argentina, Brazil, Chile, Colombia and Peru: Employment structure for industrial wage-earners, by type of contract

\begin{tabular}{cccc}
\hline & $\begin{array}{c}\text { Permanent } \\
\text { contract }\end{array}$ & $\begin{array}{c}\text { Temporary } \\
\text { contract }\end{array}$ & No contract \\
\hline $\begin{array}{c}\text { Argentina } \\
1991\end{array}$ & 67.6 & 2.2 & 30.2 \\
1998 & 62.0 & 3.6 & 34.4 \\
Brazil & & & \\
1991 & $67.9^{\mathrm{a}}$ & & 32.1 \\
1996 & $65.4^{\mathrm{a}}$ & & 34.6 \\
Chile & & & \\
1990 & 74.7 & 9.6 & 15.5 \\
1996 & 62.7 & 7.4 & 29.9 \\
Colombia & 65.4 & 7.7 & 26.9 \\
1988 & & & \\
1996 & 55.0 & 16.1 & 28.9 \\
Peru & 25.1 & 37.5 & 37.4 \\
1989 & & & \\
1997 & & & \\
\hline
\end{tabular}

Source: Prepared by the authors on the basis of national studies.

a Workers "with papers": includes workers with permanent and temporary contracts.

In the three countries whose trade openness processes began in the 1990s, the CPI grew faster than the PPI, up to 1993 in Argentina and Colombia, and up to 1994 in Peru (table 2). Since those dates, both indexes have tended to evolve along similar lines, and in Argentina the PPI has even grown faster than the CPI.

Real labour costs (deflated by the consumer price index) grew less than productivity in the period from 1990 to 1995, except in Chile (table 3). Thus, there were gains in competitiveness of around $10.2 \%$ per year in Argentina, 3.4\% in Brazil, $4.8 \%$ in Mexico and $0.6 \%$ in Peru. If we break down labour costs between wages and non-wage costs, we see that both components grew along similar lines in Brazil and Chile, ${ }^{5}$ but in Argentina non-wage labour costs grew less than wages, while the opposite occurred in Mexico and Peru.

However, in view of the different perceptions of workers and employers in this respect, we must also analyse the evolution of labour costs in relation to the PPI. As may be seen from tables 4 and 5, the growth in real labour costs is significantly greater when deflated by the PPI than by the CPI. In Argentina, the increase is $8.7 \%$ per year in the first case but there is a decline of $2.0 \%$ per year if deflated by the CPI (table 3). In Mexico and Brazil, labour costs at producer prices rise 4 times more than at consumer prices, in Peru 3 times more, and in Chile 1.6 times as fast. As a result, from the entrepreneurs' standpoint there has been a loss of competitiveness in all the countries except Mexico (table 4): a very different situation from that observed when the CPI is used, when all the countries except Chile increase their competitiveness.

All this is due to the change in relative prices resulting from the macroeconomic policies applied: on the one hand, trade openness brings with it an increase in the inflow of resources from abroad, while on the other hand there are stabilization policies using the exchange rate as an anchor. The increase in exports (mainly of primary commodities) which accompanies the openness process also helps to depress the exchange rate. This has a more rapid

\footnotetext{
${ }^{5}$ It should be noted that in Chile the reduction in non-wage labour costs took place in the early 1980 s.
}

TABLE 3

Argentina, Colombia and Peru: Annual variation in Consumer Price Index (CPI) and Producer Price Index (PPI)

\begin{tabular}{lrrrrrrrrr}
\hline & 1990 & 1991 & 1992 & 1993 & 1994 & 1995 & 1996 & 1997 \\
\hline Argentina & & & & & & & & \\
$\quad$ CPI & 1344.0 & 84.0 & 17.6 & 7.4 & 3.9 & 1.6 & 0.1 & 0.3 \\
PPI & 798.0 & 56.7 & 3.2 & 0.1 & 5.8 & 6.0 & 2.1 & -0.9 \\
Colombia & & & & & & & \\
CPI & 32.4 & 26.8 & 25.1 & 22.6 & 22.6 & 19.7 & 21.6 & 17.7 \\
PPI & 29.9 & 23.1 & 17.9 & 13.2 & 20.7 & 15.4 & 14.5 & 17.5 \\
Peru & 7650.0 & 139.0 & 56.7 & 39.5 & 15.4 & 10.2 & 11.8 & 6.5 \\
CPI & 6534.0 & 96.0 & 50.5 & 34.1 & 10.5 & 8.8 & 11.4 & 5.0 \\
PPI & & & & & & & &
\end{tabular}

Source: ECLAC. 
TABLE 4

Argentina, Brazil, Chile, Mexico and Peru: Evolution of labour competitiveness in the manufacturing sector, 1990-1995

(Values in national currency, deflated by CPI and annual growth rates)

\begin{tabular}{|c|c|c|c|c|c|}
\hline \multirow{2}{*}{ Country } & \multicolumn{3}{|c|}{ Real labour costs } & \multirow{2}{*}{ Productivity } & \multirow{2}{*}{ Competitiveness } \\
\hline & Wage & Non-wage & Total & & \\
\hline \multicolumn{6}{|l|}{ Argentina (pesos) } \\
\hline 1990 & 0.95 & 0.60 & 1.55 & & \\
\hline 1995 & 0.94 & 0.46 & 1.40 & & \\
\hline Annual variation & - & -5.2 & -2.0 & 8.0 & 10.2 \\
\hline \multicolumn{6}{|l|}{ Brazil (reales) } \\
\hline \multicolumn{6}{|l|}{1990} \\
\hline \multicolumn{6}{|l|}{1995} \\
\hline Annual variation & 2.9 & 2.9 & 2.9 & 6.4 & 3.4 \\
\hline \multicolumn{6}{|l|}{ Chile (pesos) } \\
\hline 1990 & 5.65 & 2.52 & 8.17 & & \\
\hline 1995 & 6.98 & 3.10 & 10.08 & & \\
\hline Annual variation & 4.3 & 4.2 & 4.3 & 3.6 & -0.7 \\
\hline \multicolumn{6}{|l|}{ Mexico (pesos) } \\
\hline 1990 & 4.98 & 2.33 & 7.31 & & \\
\hline 1995 & 5.21 & 2.56 & 7.77 & & \\
\hline Annual variation & 0.9 & 1.9 & 1.2 & 6.1 & 4.8 \\
\hline \multicolumn{6}{|l|}{ Peru (new soles) } \\
\hline 1990 & 0.21 & 0.12 & 0.33 & & \\
\hline 1995 & 0.26 & 0.16 & 0.42 & & \\
\hline Annual variation & 4.4 & 5.9 & 5.1 & 5.7 & 0.6 \\
\hline
\end{tabular}

Source: Prepared by the ILO.

effect on prices in the tradeables sectors (those which are most important for producers) than in the non-tradeable ones (which are most important for the workers, in their capacity of consumers). Conse- quently, the evolution of labour costs and incomes is viewed differently by those concerned, while the origin of this differential behaviour actually lies outside the labour sphere.

\section{IV}

\section{The structure of employment and labour costs, 1990-1997}

Because of limitations of information on labour costs by types of contract, this section deals with only four countries: Argentina, Chile, Colombia and Peru. The hourly labour costs of permanent, temporary and unregistered workers are compared and the average labour cost is calculated from the weighted sum of the costs for these three types of workers. A calculation is also made of the reduction observed in comparison with a situation in which there were no changes in labour legislation nor in the structure of manufacturing employment by types of contract. In the light of the growth in industrial productivity over the period in question, a calculation is made of the gains and losses in competitiveness with and without changes in the structure of employment. The costs are measured in current dollars, thus making it possible to analyse the effect of exchange rate lag on them and on competitiveness, and finally the evolution of competitiveness if there had not been an exchange rate lag is estimated.

\section{The structure of wage-earning employment in the industrial sector}

In the period analysed, the proportion of wage-earners with permanent contracts in manufac- 
turing went down, except in Colombia, while the proportion of workers with temporary contracts went up, as also (except in Colombia) did the proportion of workers without contracts (table 5).

In Argentina, the proportion of workers with permanent contracts went down by 5.6 percentage points between 1991 and 1998, while the proportions of workers with temporary contracts and those without any contract at all went up by almost 1.5 points and rather more than 4 points, respectively. In Peru, the proportion of workers with permanent contracts went down by some 30 percentage points between 1989 and 1997, while the proportion of temporary workers rose by over 20 points and that of workers without contracts grew by 9 points. In Colombia, however, the proportion of workers with permanent contracts increased by 2.7 percentage points between 1988 and 1996, the proportion of unregistered workers went down by 3 points, and that of workers with temporary contracts increased by only 0.3 points.

As a result of these changes in the structure of employment, wage-earning employment in manufacturing became more precarious in all the countries studied except Colombia, this being particularly marked in the case of Peru.

\section{Labour costs by type of contract and average labour costs}

Let us look first at the labour costs for temporary and unregistered workers, since the fact that they are lower than those of permanent workers should in theory lead to an increase in employment without a corresponding increase in lack of social protection or precarious job tenure. We will therefore analyse the contributions that employers have to pay for workers with temporary contracts and the differences in wages between permanent workers, those with temporary contracts, and those with no contract at all.

Although, as already noted, the legislation does not exempt employers from the obligation to make contributions in respect of temporary workers (except in Argentina), such contributions are smaller in absolute terms because the gross wages of these workers are lower than those of permanent workers. In 1966, temporary workers in manufacturing received $60 \%{ }^{6}$ of the wages of permanent workers in

${ }^{6}$ Other studies indicate that the average wages of temporary workers were $81.5 \%$ of those of permanent workers.
TABLE 5

Argentina, Brazil, Chile, Mexico and Peru: Evolution of labour competitiveness in the manufacturing sector, 1990-1995

(Annual growth rates, in national currency deflated by PPI)

\begin{tabular}{lrcc}
\hline Country & $\begin{array}{c}\text { Real labour } \\
\text { costs }\end{array}$ & Productivity & $\begin{array}{c}\text { Competi- } \\
\text { tiveness }\end{array}$ \\
\hline Argentina & 8.7 & 8.0 & -0.6 \\
Brazil & 12.5 & 6.4 & -5.4 \\
Chile & 6.9 & 3.6 & -3.1 \\
Mexico & 4.3 & 6.1 & 1.7 \\
Peru & 17.2 & 5.7 & -9.8 \\
\hline
\end{tabular}

Source: Prepared by the ILO.

Argentina and Chile and $64 \%^{7}$ in Colombia and Peru. As the contributions payable by employers are the same percentage of gross wages, the hourly labour cost of temporary workers in industry is lower than that of permanent workers, by the same proportion as the gross wage (34\% less in Colombia and Peru, and $40 \%$ less in Chile).

In Argentina, the hourly labour cost of temporary employees is $44 \%$ lower than that of permanent workers. Of this overall difference, $62 \%$ corresponds to wages and $38 \%$ to the exemption from employers' contributions (table 6).

In the light of the wage differences reported by the four countries in question (insufficient information is available for Brazil) and the partial exemption from employers' contributions in Argentina, an estimate can be made of the differences in hourly costs by type of contract (tables 6 and 7). This estimate shows that the cost of hiring a temporary worker is between $56 \%$ and $65 \%$ of the cost of hiring a permanent employee.

The potential effect of the lower cost of hiring temporary workers on the average labour costs of a firm depends on the percentage of the total number of jobs that can legally be filled with temporary workers under forms of contract promoted by the legislation. In Argentina, this percentage cannot be more than $30 \%$ in the case of firms with over 25 workers, it can be up to $50 \%$ in firms with between 6 and 25 workers, and there is no limit in the case of

\footnotetext{
${ }^{7}$ These figures refer to the average wages for each group. The differences grow smaller as the workers' years of schooling increase. Thus, the average wages of workers with a university education are not significantly different, regardless of whether they have temporary or permanent contracts.
} 
Argentina, Brazil, Chile, Colombia and Peru: Hourly labour costs of workers with permanent and temporary contracts in manufacturing (Current dollars)

\begin{tabular}{|c|c|c|c|c|c|c|c|}
\hline & \multicolumn{3}{|c|}{ Permanent } & \multicolumn{3}{|c|}{ Temporary (1-year contract) } & \multirow{2}{*}{$\begin{array}{c}\text { Cost of } \\
\text { temporary } \\
\text { workers/cost } \\
\text { of permanent } \\
\text { workers }\end{array}$} \\
\hline & Wage & $\begin{array}{c}\text { Non-wage } \\
\text { cost }\end{array}$ & Total & Wage & $\begin{array}{c}\text { Non-wage } \\
\text { cost }\end{array}$ & Total & \\
\hline Argentina, 1998 & 4.57 & 1.96 & 6.53 & 2.76 & 0.87 & 3.63 & 0.56 \\
\hline Brazil, 1996 & 3.74 & 2.18 & 5.92 & $\ldots$ & $\ldots$ & $\ldots$ & $\ldots$ \\
\hline Chile, 1996 & 2.37 & 0.91 & 3.28 & 1.43 & 0.54 & 1.97 & 0.60 \\
\hline Colombia, 1996 & 1.44 & 0.76 & 2.20 & 0.91 & 0.49 & 1.40 & 0.64 \\
\hline Peru, 1997 & 1.29 & 0.83 & 2.12 & 0.83 & 0.54 & 1.37 & 0.65 \\
\hline
\end{tabular}

Source: Prepared by the ILO on the basis of official country data and case studies.

TABLE 7

\begin{abstract}
Argentina, Brazil, Chile, Colombia and Peru: Labour costs of workers with and without contracts, 1996 (Current dollars)
\end{abstract}

\begin{tabular}{|c|c|c|c|c|c|}
\hline & \multicolumn{2}{|c|}{ With contract } & \multirow{2}{*}{ Without contract } & \multicolumn{2}{|c|}{$\begin{array}{l}\text { Cost without contract/ } \\
\text { cost with contract }\end{array}$} \\
\hline & Permanent & Temporary & & Temporary & Permanent \\
\hline Argentina, 1998 & 6.53 & 3.63 & 3.01 & 0.83 & 0.46 \\
\hline Brazil, 1996 & 5.92 & $\ldots$ & 1.26 & $\ldots$ & 0.21 \\
\hline Chile, 1996 & 3.28 & 1.97 & 1.37 & 0.70 & 0.42 \\
\hline Colombia, 1996 & 2.20 & 1.40 & 0.90 & 0.64 & 0.41 \\
\hline Peru, 1997 & 2.12 & 1.32 & 1.01 & 0.76 & 0.48 \\
\hline
\end{tabular}

Source: Prepared by the authors on the basis of national studies.

firms with less than 6 employees. In Chile, Colombia and Peru the legislation does not specify any limit on the proportion of such contracts.

Consequently, in a medium-sized firm which can fill up to $30 \%$ of its jobs with temporary workers, the use of the forms of contracts promoted by the legislation would make it possible to reduce average labour costs by around $13 \%$ in Argentina, $43 \%$ in Chile, 34\% in Colombia and 38\% in Peru. It should be noted, however, that in Chile this reform was introduced in 1978, so that its effect on the reduction of labour costs took place before the period studied.

\section{The labour cost of unregistered workers}

The non-wage labour costs of unregistered workers are lower than those of workers with contracts, not only because employers pay only a part of the legally established contributions but also because such workers' gross wages are lower.

With regard to the contributions that should be paid by the employer, it is believed that unregistered workers do receive deferred wages (such as holidays and bonuses), but there are doubts as to whether the benefits in respect of holidays and extraordinary payments are the same for both registered and unregistered workers. Szretter (1999) estimates that on average unregistered workers receive only half the deferred wages of workers with temporary contracts, i.e., $6.6 \%$ of gross wages compared with $13.2 \%$ in the case of temporary workers. For the purposes of the present study, however, we have assumed that workers without a contract receive the same benefits as workers with temporary contracts in respect of holidays and supplementary payments, which would amount to $13.2 \%$ of gross wages in Argentina, $11.3 \%$ 
TABLE 8

Argentina, Brazil, Chile, Colombia and Peru: Hourly labour costs in manufacturing

(Current dollars)

\begin{tabular}{|c|c|c|c|c|c|c|c|c|c|c|c|c|c|c|c|}
\hline & \multicolumn{3}{|c|}{ Argentina } & \multicolumn{3}{|c|}{ Brazil } & \multicolumn{3}{|c|}{ Chile } & \multicolumn{3}{|c|}{ Colombia } & \multicolumn{3}{|c|}{ Peru } \\
\hline & PERM $^{\mathrm{a}}$ & AVER $^{\mathrm{b}}$ & $\mathrm{DIFF}^{\mathrm{c}}$ & PERM & AVER & DIFF & PERM & AVER & DIFF & PERM & AVER & DIFF & PERM & AVER & DIFF \\
\hline 1988 & $\ldots$ & $\ldots$ & - & - & - & - & $\ldots$ & $\ldots$ & - & 1.1 & 0.9 & $18 \%$ & $\ldots$ & $\ldots$ & - \\
\hline 1989 & $\ldots$ & $\ldots$ & - & 2.37 & 1.84 & $22 \%$ & $\ldots$ & $\ldots$ & - & $\ldots$ & $\ldots$ & - & 0.96 & 0.81 & $16 \%$ \\
\hline 1990 & $\ldots$ & $\ldots$ & - & 2.25 & 1.73 & $23 \%$ & 2.54 & 2.2 & $13 \%$ & $\ldots$ & $\ldots$ & - & $\ldots$ & $\ldots$ & - \\
\hline 1991 & 4.55 & 3.64 & $20 \%$ & 2.32 & 1.77 & $24 \%$ & $\ldots$ & $\ldots$ & - & $\ldots$ & $\ldots$ & - & $\ldots$ & $\ldots$ & - \\
\hline 1996 & 6.33 & 5.04 & $20 \%$ & 5.92 & 4.2 & $29 \%$ & 3.4 & 2.95 & $13 \%$ & 2.1 & 1.7 & $19 \%$ & 2.2 & $\ldots$ & - \\
\hline 1997 & 6.31 & 5.12 & $19 \%$ & 5.17 & 3.67 & $29 \%$ & 3.49 & 3.03 & $13 \%$ & 2.37 & 1.92 & $19 \%$ & 2.12 & 1.73 & $18 \%$ \\
\hline
\end{tabular}

Source: Country studies by ILO.

${ }^{a}$ Hourly labour cost of workers with permanent contracts.

${ }^{b}$ Average hourly labour cost of all workers in manufacturing.

${ }^{c}$ Difference between hourly costs.

in Brazil, $27.1 \%$ in Chile, $14.1 \%$ in Colombia and $29.7 \%$ in Peru. ${ }^{8}$

The gross wages of unregistered workers are lower than those of workers with permanent or temporary contracts. In the hypothetical situation assumed above, the wages of workers without contracts in the last year of the period studied would represent $94 \%$ of the wages of temporary workers and $58.3 \%$ of those of permanent employees in Argentina, $91 \%$ and $53 \%$ respectively in Chile, and $94 \%$ and $62 \%$ in Colombia, while in Peru they would be similar to those of workers with temporary contracts. In Brazil (where no information is available on the average wages of workers with temporary contracts), in 1996 the wages of workers "without papers" were $30 \%$ of those of workers "with papers".

Thus, the cost of employing a worker without a contract would be $17 \%$ less than the cost of a temporary employee in Argentina, 30\% less in Chile, 36\% less in Colombia, and $24 \%$ less in Peru, while the difference would be much greater compared with a permanent employee (54\% less in Argentina, 58\% in Chile, $59 \%$ in Colombia, $52 \%$ in Peru and $79 \%$ in Brazil).

\footnotetext{
${ }^{8}$ The higher proportions in the cases of Chile and Peru are due to the assumption that workers with and without contracts both receive two extraordinary payments equivalent to the average monthly wage in Peru and annual bonuses equivalent to $25 \%$ of their gross monthly wages in Chile.
}

\section{Average labour costs}

On the basis of the labour costs for each type of contract and structure of employment in manufacturing (table 2), we can calculate the average hourly labour costs for the period studied. Thus, in 1997 such costs came to 5.12 current dollars in Argentina, 3.67 in Brazil, 3.03 in Chile, 1.92 in Colombia and 1.73 in Peru (table 8).

These average costs are between $13 \%$ and $29 \%$ lower than they would be if all workers had permanent contracts. ${ }^{9}$ As may be seen from table 8, the difference would be $29 \%$ in Brazil, $19 \%$ in Argentina and Colombia, and $18 \%$ in Peru. Although this difference went down slightly over the last seven years in Argentina, it remained unchanged in Colombia and increased in Peru. This different behaviour is explained by the fact that although the proportion of workers without contracts or with temporary contracts increased in Argentina, there was a reduction (from $70 \%$ in 1991 to $85 \%$ in 1997) in the relative wage differential between unregistered and permanent employees. ${ }^{10}$ In Peru, the increased difference is due

\footnotetext{
${ }^{9}$ This is a theoretical maximum reduction, since it is not feasible for all the workers in firms (public or private) to have permanent contracts.

10 The evolution of wage differentials in Argentina should be viewed with caution, because "unregistered workers" may include professionals providing services to firms without being registered on the payroll. The salaries of such professionals are usually higher than the average and also grow faster.
} 
to the fact that there were increases both in the proportion of workers with temporary contracts or without any contracts at all and in the wage differentials.

The estimated average labour costs are not only lower than those that would have been registered if all workers had permanent contracts but also lower (except in Colombia) than those that would have applied if the employment structure obtaining in the first year of the period studied had been maintained. Thus, in 1997 the labour cost would have been 5.32 dollars instead of 5.12 dollars in Argentina (3.8\% higher) and 3.77 dollars instead of 3.67 dollars in Brazil (2.7\% higher). Only in Colombia would they have been lower (1.89 dollars instead of 1.92 dollars (1.6\% lower). This has been the main economic effect of the more flexible rules on contracts. In a context in which the exchange rate is used as an anchor for stabilization policies, such flexibility should facilitate adjustment of the labour market and enable the reduction in average labour costs, for a given level of productivity, to be reflected in higher competitiveness.

\section{Labour costs, productivity and competitiveness}

\section{Labour costs and competitiveness}

In the 1990s the average labour costs in manufacturing (in current dollars) rose by $5.9 \%$ per year in Argentina, $9.0 \%$ in Brazil, $4.7 \%$ in Chile, $8.8 \%$ in Colombia and $9.9 \%$ in Peru (table 9).

This significant increase (largely related to the exchange rate lag registered in that decade) was less than the increase in productivity ${ }^{11}$ in Argentina (9.4\% per year) and Chile $(7.8 \%)$ but higher in Brazil (5.3\%), Colombia (3.5\%) and Peru (3.4\%). Consequently, industrial productivity rose by around

\footnotetext{
${ }^{11}$ In terms of the gross value of output per worker, in current dollars.
} TABLE 9

Selected countries: Evolution of average labour costs, productivity and competitiveness

(Annual rates)

\begin{tabular}{|c|c|c|c|c|c|c|c|}
\hline & \multicolumn{3}{|c|}{ Cost } & \multirow{2}{*}{$\begin{array}{l}\text { Produc- } \\
\text { tivity }\end{array}$} & \multicolumn{3}{|c|}{ Competitiveness $^{\mathrm{a}}$} \\
\hline & $\begin{array}{l}\text { With } \\
\text { change }\end{array}$ & & $\begin{array}{l}\text { Without } \\
\text { change }\end{array}$ & & $\begin{array}{c}\text { With } \\
\text { change }\end{array}$ & & $\begin{array}{l}\text { Without } \\
\text { change }\end{array}$ \\
\hline United States, 1990-1996 & & 2.9 & & 4.4 & & 1.5 & \\
\hline South Korea, 1990-1996 & & 14.2 & & 12.0 & & -1.9 & \\
\hline Germany, 1990-1996 & & 2.1 & & 6.2 & & 4.0 & \\
\hline Argentina, 1991-1997 & 5.9 & & 6.5 & 9.4 & 3.3 & & 2.7 \\
\hline Brazil, 1989-1997 & 9.0 & & 9.4 & 5.3 & -3.4 & & -3.7 \\
\hline Chile, 1990-1997 & 4.7 & & $\ldots$ & 7.8 & 3.0 & & \\
\hline Colombia, 1988-1997 & 8.8 & & 8.6 & 3.5 & -4.9 & & -4.7 \\
\hline Peru, 1989-1997 & 9.9 & & 12.2 & 3.4 & -5.9 & & -7.8 \\
\hline
\end{tabular}

Source: Prepared by the ILO.

${ }^{\mathrm{a}}$ Calculated through the following formula:

$c=\frac{(1+q)}{(1+1 c)}-1$

where

$\mathrm{c}=$ annual variation in competitiveness

$\mathrm{q}=$ annual variation in productivity

$\mathrm{lc}=$ annual variation in labour costs

b i.e., change in employment structure, by type of contract. 
$3.0 \%$ per year in Argentina and Chile but went down in Brazil $(-3.4 \%$ per year), Colombia $(-4.9 \%$ and Peru $(-5.9 \%)$.

The growth of competitiveness in Argentina and Chile was higher than that registered in the United States and South Korea between 1990 and 1996, due mainly to the rapid increase in productivity in the two Latin American countries, while the loss of competitiveness of Brazil, Colombia and Peru (which even exceeded the corresponding loss in Korea) was due both to the rapid increase in labour costs and to the modest growth of productivity.

How would competitiveness have evolved if in 1997 the employment structure in each country had remained the same as that obtaining in the first year of the period studied? The results indicate that in Argentina labour costs would have been $3.8 \%$ higher than those actually registered, in Brazil $2.7 \%$ higher, in Peru $15 \%$ higher, and in Colombia 1.6\% lower. This means that hourly labour costs would have increased more per year than they did with the change of structure in Argentina, Brazil and Peru, but slightly less in Colombia. Thus, in Argentina, Brazil and Peru industrial competitiveness would have increased $0.5 \%, 0.2 \%$ and $1.9 \%$ less than it actually did, respectively, while in Colombia the loss of competitiveness would have been 0.2 percentage points less (table 9).

The introduction of more precarious forms of employment made it possible to reduce labour costs because of the lower non-wage costs in Argentina and because of the lower wages for non-permanent labour in all the countries studied. Thus, Argentina was able to increase its competitiveness in spite of the fixed exchange rate and it was possible to partly offset the loss of competitiveness due to slow productivity growth and exchange rate lag in Brazil, Colombia and Peru.

The increase in labour costs in dollars was due to the increase in nominal wages in a context of exchange rate lag. Increased productivity, for its part, was due mainly to the reduction in the level of employment. $^{12}$ The evolution of competitiveness has thus been determined by the influence of changes in the employment structure and exchange rate policies on labour costs and the effect of lower levels of employment on productivity.

\footnotetext{
${ }^{12}$ See Amadeo, Camargo, Frenkel and Hernández-Laos, 1999.
}

\section{Labour costs and the effective exchange rate}

In the period studied, most of the countries in question displayed over-valuation of the national currency and exchange rate lags, due both to the inflow of foreign capital and to the use of the exchange rate as an anchor in stabilization policies. In others, however, the exchange rate policies applied linked the local currency to the relation between domestic and external inflation, so that the exchange rate maintained its parity and rose at the same rate as inflation, or even faster. In the latter case, there was undervaluation of the national currency or devaluation in real terms.

Real gains in labour competitiveness will occur when the growth rate of labour productivity is higher than that of labour costs and is also sufficient to offset the effects of exchange rate lag.

If we include in the analysis the effects produced by exchange rate lag, using the effective exchange rate given by the behaviour of the national currency vis-à-vis those of the country's main trading partners, the levels of competitiveness given in table 9 change significantly.

Let us now look at the evolution of manufacturing competitiveness after correcting the lags or advances of the effective exchange rate (tables 10 and 11).

When this is done, the competitiveness gains are reduced and the losses increase in countries like South Korea and Germany, which devalued their currencies to less than the equilibrium or parity level with the currencies of their main trading partners. In contrast, in countries like Argentina, Brazil, Chile, Colombia and Peru, which had overvalued currencies, exchange rate correction increases the gains in competitiveness by Argentina and Chile, reduces the losses of Colombia and Peru, and turns Brazil's loss into a gain.

In these circumstances, if we look at the behaviour by countries we see that in the period studied the manufacturing productivity of Argentina, Brazil, Chile, Colombia and Peru rose significantly, but not as fast as labour costs in the cases of Brazil, Colombia and Peru (table 9), so that they suffered competitiveness losses of $3.4 \%, 4.9 \%$ and $5.9 \%$ respectively. The situation was different in Argentina and Chile, where productivity rose faster than average labour costs, giving rise to competitiveness gains of the order of $3.3 \%$ and $3.0 \%$ respectively. If we introduce exchange rate correction, however (table 10), the gains in competitiveness would be still greater in the 
TABLE 10

Selected countries: Evolution of labour competitiveness in manufacturing after exchange-rate correction

\begin{tabular}{|c|c|c|c|c|}
\hline & $\begin{array}{c}\text { Productivity } \\
\text { (base year=100) }\end{array}$ & $\begin{array}{c}\text { Labour costs } \\
\text { (base year }=100 \text { ) }\end{array}$ & $\begin{array}{l}\text { Effective exchange rate } \\
\quad(\text { base year }=100)\end{array}$ & $\begin{array}{c}\text { Annual variation in } \\
\text { competitiveness }^{\mathrm{a}}\end{array}$ \\
\hline United States, 1990-1996 & 129.5 & 118.7 & 96.9 & 2.0 \\
\hline South Korea, 1990-1996 & 197.4 & 221.8 & 118.0 & -4.6 \\
\hline Germany, 1990-1996 & 143.5 & 113.3 & 122.5 & 0.6 \\
\hline Argentina, 1991-1997 & 171.4 & 141.1 & 71.3 & 9.3 \\
\hline Brazil, 1989-1997 & 151.2 & 199.3 & 64.5 & 2.0 \\
\hline Chile, 1990-1997 & 169.2 & 137.9 & 87.2 & 5.0 \\
\hline Colombia, 1988-1997 & 136.3 & 213.6 & 64.7 & -0.2 \\
\hline Peru, 1989-1997 & 130.7 & 212.8 & 91.8 & -4.9 \\
\hline
\end{tabular}

Source: Table 9 above and ECLAC for effective exchange rate.

a Calculated through the following formula:

$$
c=\left[\frac{(1+q)(1+\text { er })}{(1+\mathrm{lc})}\right]-1
$$

where $c$ is the annual variation in competitiveness, $q$ is the annual variation in productivity, er is the annual variation in the effective exchange rate, and $l c$ is the annual variation in labour costs.

TABLE 11

Selected countries: Variation in competitiveness of manufacturing

\begin{tabular}{lcc}
\hline & $\begin{array}{c}\text { With } \\
\text { exchange } \\
\text { rate lag or } \\
\text { advance }\end{array}$ & $\begin{array}{c}\text { Without } \\
\text { exchange } \\
\text { rate lag or } \\
\text { advance }\end{array}$ \\
\hline United States, 1990-1996 & 1.5 & 2.0 \\
South Korea, 1990-1996 & -1.9 & -4.6 \\
Germany, 1990-1996 & 4.0 & 0.6 \\
Argentina, 1991-1997 & 3.3 & 9.3 \\
Brazil, 1989-1997 & -3.4 & 2.0 \\
Chile, 1990-1997 & 3.0 & 5.0 \\
Colombia, 1988-1997 & -4.9 & -0.2 \\
Peru, 1989-1997 & -5.9 & -4.9 \\
\hline
\end{tabular}

Source: Tables 9 and 10 above.

cases of Argentina and Chile (9.3\% and 5.0\% per year, respectively), the losses would be smaller in Colombia (-0.2\%) and Peru (-4.9\%), and Brazil's loss would be turned into a gain of $2.0 \%$.

With regard to countries outside the region, we see that Germany's gain in competitiveness would have been smaller if it had not devalued its currency, while South Korea's loss would have been greater. In the case of the United States, its gain in competitiveness would be slightly greater if account is taken of the evolution of the dollar compared with the currencies of its main trading partners.
To sum up, the analysis made so far shows that the competitiveness of countries depends both on the decisions taken by employers and workers that affect labour costs and productivity and the macroeconomic policies applied. During the period studied, the exchange rate lag that existed in many countries of the region made nominal labour costs higher and reduced export income in national currency terms, giving rise to loss of competitiveness in most cases.

As already noted, the exchange rate policies applied have been influenced by the inflow of short-term foreign capital as a result of the opening-up of markets, as well as by the stabilization policies applied. In the case of the countries studied here, globalization would therefore appear to have had not only the well-known positive effects but also an exchange-rate effect which, so far, has adversely affected manufacturing competitiveness. Furthermore, globalization shifts the burden of domestic adjustment onto costs (especially labour costs) and productivity. The evolution of labour costs in the countries studied affects competitiveness, but this effect depends on the evolution of productivity and also on the effects of macroeconomic policies. Indeed, during the period in question these factors were more important than the evolution of wages and wage-based taxes to finance social security benefits.

The incidence of exchange rate policy on labour costs and competitiveness was clearly shown by the devaluations made by all the countries except Argen- 
tina to compensate for the effects of the maxi-devaluations effected by the Asian countries in 1997.

\section{Labour costs and competitiveness in the context of the Southeast Asian crisis}

The measures taken by the Southeast Asian countries to deal with the crisis that affected them as from the second half of 1997 forced Latin American firms to make greater efforts in order at least to maintain their levels of relative competitiveness vis-à-vis those countries.

The devaluations made by the Southeast Asian countries led to reductions in labour costs in dollar terms between the first half of 1997 and the first half of 1998 which amounted to $24.8 \%$ in Thailand, $28.1 \%$ in the Philippines, $33.1 \%$ in South Korea, $34.9 \%$ in Indonesia and $38.4 \%$ in Malaysia. This reduction in labour costs occurred in the midst of a generalized contraction of real wages due to the speeding-up of inflation in all these countries. At the same time, average labour productivity in the manufacturing sector also declined because employment did not go down in proportion to the abrupt drop in industrial production during the adjustment (ILO, 1998).

As a result of the evolution of labour costs and productivity, manufacturing sector productivity rose significantly in all the Southeast Asian countries during the first half of 1998 as compared with the same period the year before, with the gains in competitiveness ranging from $40 \%$ to $60 \%$, except in Thailand (21.4\%).

Consequently, the competitiveness of the Latin American countries would have had to increase by between $20 \%$ and $60 \%$ in 1998 merely in order to maintain their pre-crisis levels of relative competitiveness. As it was difficult, if not impossible, to make a fresh reduction in labour costs of this magnitude and it was not possible either to raise productivity by the same amount in the short term, the only possibility was to reorient exchange-rate policy: i.e., to devalue the national currency more in order to reduce costs in dollar terms.

Between the first half of 1996 and the first half of 1997 (that is to say, the twelve months before the Asian crisis) there were substantial gains in manufacturing sector competitiveness in all the countries studied except Chile, where there was a decline of $4.1 \%$ (figure 1 ). The increase in productivity in those
FIGURE 1

Argentina, Brazil, Chile, Colombia and Peru: Annual variation in labour costs, productivity and competitiveness in the manufacturing sector (First half of 1996-first half of 1997)

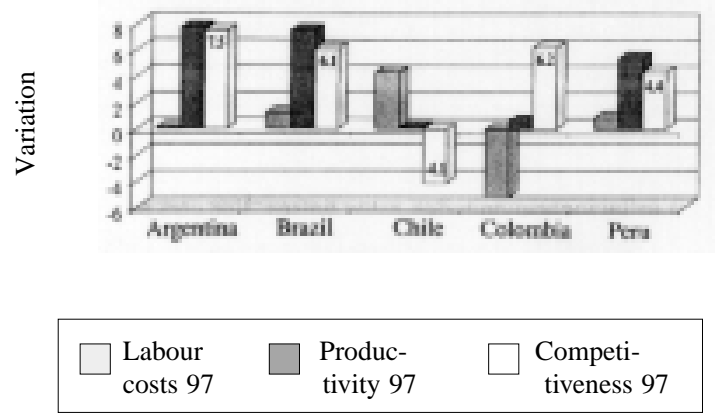

FIGURE 2

Argentina, Brazil, Chile, Colombia and Peru: Annual variation in labour costs, productivity and competitiveness in the manufacturing sector (First half of 1997-first half of 1998)

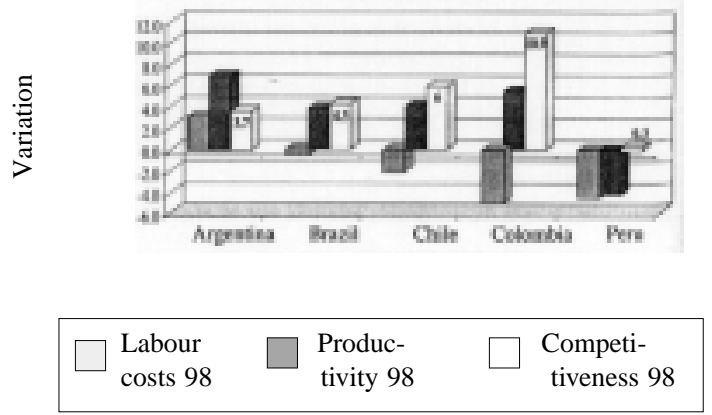

twelve months (Argentina: $7.5 \%$; Brazil: $6.1 \%$ and Peru: $4.4 \%$ ) was due to the rapid growth of output per hour worked $(5.4 \%$ in Peru and $7.5 \%$ in Argentina and Brazil), while labour costs rose by only $0.2 \%$ in Argentina and a little over $1.0 \%$ in Brazil and Peru. In Colombia, the $6.2 \%$ increase in competitiveness was due entirely to the reduction in labour costs in dollars because of the devaluation of the peso, since productivity rose by only $0.7 \%$.

In contrast with the foregoing, the evolution of labour costs and productivity in the context of the Asian crisis -that is to say, between the first half of 1997 and the first half of 1998- indicates that labour costs went down in all the countries except Argentina (by $0.4 \%$ in Brazil, $1.9 \%$ in Chile, $4.9 \%$ in Colombia and $4.3 \%$ in Peru) (figure 2). Obviously, these reduc- 
tions -which took place even though real wages increased (except in Argentina and Peru) because the adjustment was being carried out without increasing inflation- were associated with the major (Chile, Colombia and Peru) or minor (Brazil) devaluations of the respective national currencies in these twelve months. Parallel with this reduction in labour costs in dollar terms, all the countries except Peru registered increases in productivity (physical output per hour worked): $3.9 \%$ in Brazil, $4 \%$ in Chile and $5.4 \%$ in Colombia. This caused competitiveness to rise by between $4.3 \%$ (Brazil) and 10.9\% (Colombia) (figure 2). In Peru, although labour costs in dollar terms went down due to the devaluation, productivity dropped by $4 \%$, so that the rise in competitiveness was only $0.3 \%$. In Argentina, although labour costs increased in dollar terms, competitiveness neverthe-

\section{V}

\section{Conclusions}

At least five conclusions may be drawn from the analysis made in this study. Firstly, there was a change in the structure of private sector employment in terms of forms of hiring. There was an increase in the proportion of workers with temporary contracts or no contract at all (except, in the latter case, in Colombia) and a decrease in the proportion with permanent contracts.

Secondly, in some countries the rates of contributions payable by employers in respect of workers with temporary contracts were reduced to promote the hiring of such workers.

Thirdly, as a result of the foregoing, average labour costs (calculated by weighting the labour costs by type of contract by the weight of such contracts in total employment) rose less than would have been the case if there had not been a change in the structure of wage labour and an accentuation in wage differences. Consequently, some countries obtained greater competitiveness gains than they would have attained in the absence of such changes, while others suffered less serious losses of competitiveness than they would otherwise have undergone. The only exception was Colombia, where the changes led to a slightly greater increase in labour costs than would otherwise have been the case. less rose by $3.7 \%$ thanks to the $6.8 \%$ increase in productivity due to both the growth of physical output and a slight reduction in manufacturing sector employment.

To sum up, then, the increases in productivity obtained in some countries thanks to the expansion of industrial output and lower levels of manufacturing sector employment, as well as the devaluations made in other countries, which helped to reduce labour costs in dollars, made it possible to improve competitiveness in the twelve months following the onset of the Asian crisis. Nevertheless, this did not prevent a loss of relative competitiveness, because as already noted, the Asian countries increased their competitiveness even more, thanks to the reduction of their labour costs in dollar terms rather than to increases in productivity.
Fourthly, even in those countries which registered losses of competitiveness (Brazil, Colombia and Peru), these were not due to a drop in productivity but to rapid increases in labour costs expressed in current dollars. These increases were due partly to increases in real wages, but mainly to exchange rate lags which drove up labour costs significantly. As we saw in the previous section, the correction of these lags in 1998 made it possible to reduce labour costs and thus partly compensate for the loss of competitiveness generated by the maxi-devaluations registered in the Southeast Asian countries.

Fifthly, it does not seem likely that recovery of the competitiveness lost after the Asian crisis and, more recently, the problems in Brazil, can be based on spectacular increases in productivity or on the reduction of labour costs through the promotion of more precarious forms of employment, the contraction of nominal wages, or a significant reduction in employers' contributions. ${ }^{13}$ Consequently, competitiveness gains should be based, in the short term, on the reorientation of exchange and interest-rate poli-

\footnotetext{
${ }^{13}$ This does not mean that efforts should not be made to reduce or eliminate contributions which do not generate benefits for the workers, especially in the case of microenterprises or small-scale enterprises.
} 
cies and, in the longer term, on strategies to raise productivity which involve both employers and workers.

Such strategies would affect labour policy as regards labour relations, both individual and collective. With regard to individual relations, a matter for concern are the effects of more precarious forms of employment on both the security and personal and family development of workers and on the development of their productivity potential, especially if their possibilities of participating in training and retraining programmes and activities are only limited.

It would be desirable to explore the possibility of reducing the proportion of temporary workers and providing incentives for stable employment by reducing the cost of longer-term contracts. In addition, unemployment insurance arrangements should be developed, combined with training programmes for those receiving such benefits, designed to improve the "employability" of workers and -if made compulsory throughout the period when a worker is receiving unemployment benefit- to discourage protracted unemployment.

Collective labour relations (more specifically collective negotiation) form the second area for efforts to raise productivity. It is necessary to progress from a vision of collective negotiation seen as a means for avoiding over-exploitation of workers and achieving social peace to the concept of collective negotiation as a means of arriving at undertakings between workers and employers to apply strategies that will raise productivity and share its benefits more equitably.

One such strategy could be to establish a link between wages and productivity, so that, after fixing a minimum level determined by the existing wage level, all wage increases during the agreed period must be tied to the productivity increases obtained, measured according to formulas agreed between both sides.

Another strategy negotiated between employers and workers could be to promote participation by the latter in decisions on the organization of the various stages in the production process and quality control and establish incentives for the submission of proposals for raising productivity.

Likewise, concerted training plans could be established through collective negotiation within the enterprises, which, like the other incentives, would result in productivity increases in both the short and long term.

In short, the recovery of lost competitiveness and the attainment of further advances in this respect should be based on increases in productivity rather than on cost reductions achieved through more precarious job tenure or a lower level of employment. Greater job security and the promotion of collective negotiation can help to secure sustained increases in productivity.

(Original: Spanish)

\section{Bibliography}

Amadeo, E., J.J. Camargo, R. Frenkel and E. HernándezLaos (1999): Apertura comercial, productividad y empleo, Lima, International Labour Organisation (ILO).

Chacaltana, J. (1999): Costos laborales en Perú, in V.E. Tokman and D. Martínez (eds.), Costos laborales sectoriales y modalidades de contratación, Lima, ILO (in the press).

Chacón, B. (1999): Costos laborales en Chile, in V. E. Tokman and D. Martínez (eds.), Costos laborales sectoriales y modalidades de contratación, Lima, ILO (in the press).

ECLAC (Economic Commission for Latin America and the Caribbean) (1998): Statistical Yearbook for Latin America and the Caribbean 1997, Santiago, Chile.

Hofman, A. (1996): The historical experience: growth accounting, in Buitelaar, R. and P. Van Dijck (eds.), Latin America's New Insertion in the World Econ- omy: Towards Systemic Competitiveness in Small Economies, Macmillan.

ILO (1997): Costos laborales y competitividad industrial en América Latina, Lima.

(1998): Panorama laboral '98, Geneva.

Pochman, M. (1999): Costos laborales en Brasil, in V. E. Tokman and D. Martínez (eds.), Costos laborales sectoriales y modalidades de contratación, Lima, ILO (in the press).

Szretter, H. (1999): Costos laborales en Argentina, in V.E. Tokman and D. Martínez (comps.), Costos laborales sectoriales y modalidades de contratación, Lima, ILO, (in the press).

Tokman, V.E. and D. Martínez (1998): La agenda laboral en la globalización. Eficiencia económica con progreso social, Viña del Mar, Chile.

-(eds.) (1999): La flexibilización en el margen. La reforma del contrato de trabajo, Lima, ILO. 